\title{
Smartphones for Learning in Rural University Classrooms: A South African Perspective
}

\author{
Simon Christopher Fernandez ${ }^{1, *}$, John Percival Fernandez ${ }^{2}$ \\ ${ }^{1}$ Faculty of Science, Engineering and Technology, Walter Sisulu University, East London, South Africa \\ ${ }^{2}$ Faculty of Business Sciences, Walter Sisulu University, East London, South Africa
}

Received August 22, 2021; Revised September 26, 2021; Accepted October 28, 2021

\begin{abstract}
Cite This Paper in the following Citation Styles
(a): [1] Simon Christopher Fernandez, John Percival Fernandez, "Smartphones for Learning in Rural University Classrooms: A South African Perspective," Universal Journal of Educational Research, Vol. 9, No. 11, pp. 1805 - 1813, 2021. DOI: 10.13189/ujer.2021.091101.
\end{abstract}

(b): Simon Christopher Fernandez, John Percival Fernandez (2021). Smartphones for Learning in Rural University Classrooms: A South African Perspective. Universal Journal of Educational Research, 9(11), 1805 - 1813. DOI: 10.13189/ujer.2021.091101.

Copyright $\odot 2021$ by authors, all rights reserved. Authors agree that this article remains permanently open access under the terms of the Creative Commons Attribution License 4.0 International License

\begin{abstract}
The study examined the views of lecturers and Peer Assisted Learning (PAL) Tutors on students' use of smartphones for learning at a rural university in the Eastern Cape Province of South Africa. The research adopted a quantitative approach and the design was a survey. A total sample of 50 academics that was comprised of 39 lecturers from the Faculty of Business Science \& Management and Faculty of Science, Engineering \& Technology from a population of 71 and 11 PAL Tutors from Faculty of Science, Engineering \& Technology from a population of 14 voluntarily partook in the survey. A five-point Likert-scale questionnaire was employed to collect data. The questionnaire consisted of two sections in which the first section was used to obtain the demographic data and the second section to collect the core data. The quantitative data were captured into Statistical Package for Social Sciences (version 26) which were analyzed using descriptive statistics and triangulated by sources among lecturers and PAL Tutors. The results obtained revealed that the lecturers and PAL Tutors showed positive attitudes on the students' use of smartphones in university classrooms. It has been strongly established that students do not have the multitasking capability of using smartphones and paying attention to lecture at the same time. Furthermore, this study also showed that use of smartphones for academic purposes in university classrooms were enjoyed by the students and it was motivating and enhancing their learning process.
\end{abstract}

Keywords Smartphone, Learning, Cell Phone,
Educational Technology, Mobile Technology, Rural University Education, Lecturers, Peer Assisted Learning Tutors

\section{Introduction}

In the world of $21^{\text {st }}$ century, mobile technologies have become an integral part in all the sectors universally. As the influence of mobile technologies are high, many institutions around the world are seeking the help of hand-held devices such as laptop [1, 2, 3, 4], iPad [5, 6, 7, 8], iPod [9, 10. 11], cell phone [12, 13] with an aim to enhance the learning skills of students. When these technologies are blended with traditional approach, it helps the students to explore and enhance their learning skills $[14,15]$.

The impact of smartphones and other handheld devices have transformed learning and teaching remarkably in universities not only in developed countries but also in developing countries [16]. Smartphones aid students in enhancing their learning using internet at anytime, anywhere [17]. For instance, smartphones can be used to download e-books, online lectures which are recorded [18]. They can also be used to take photos of the concepts that are written on the board using its camera to relate them with concrete ideas at a later stage especially for distance learning programmes [19]. A study conducted in 
university of Hong Kong and university of Tsukuba (Japan) found that students were using smartphones for the academic purposes such as to access the learning materials, lecture notes, engage and collaborate with classmates [20]. Another study conducted in Saudi Arabia was not able to decide whether smartphone affected their learning or not as most of the students indicated a neutral stance [21], where as in Ghana, a study found that smartphones had great potential as a gadget for learning and can be used positively for the purpose of learning and teaching in the field of Science [22].

South Africa is the second largest mobile market in African continent and mobile penetration rate is much higher than the other West-African countries [23]. Majority of the higher education students in South Africa own smartphone [24] and the use of smartphones among students in South African universities are increasing daily [25]. However, there are numerous hindrances that are hampering the mobile learning in the African context such as less network coverage and data issues. Furthermore, the internet bandwidth is low and study materials are not mobile friendly in the institutions [26]. These challenges such as less network coverage, data issues, low internet bandwidth and unfriendly mobile study materials are highly affecting the students' learning using smartphones. Consequently, it is very significant to investigate on the students' use of smartphones for learning in higher education. Additionally, adequate studies based on students' use of smartphones for the effect of learning are still far less [27, 28, 29] especially from rural universities in the Eastern Cape province of South Africa. Masiu and Chukwuere [30 p.174] argue that "there are as yet insufficient empirical studies that cover the effective application of smartphones by students in achieving their academic learning journey”. Moreover, studies examining the views of PAL Tutors and lecturers on the use of students' mobile learning using smartphones are inadequate which makes this study more worthy to be investigated. PAL Tutors are the expert students in a particular course who are recruited by the Centre for Learning and Teaching Department of the university to assist the lecturers in teaching their students. Therefore, the objective of this study is to fathom the views of lecturers and PAL Tutors on students' use of smartphones for learning at a rural university in the Eastern Cape Province of South Africa. The research question of this study is: What are the views of lecturers and PAL Tutors on students' use of smartphones for learning in rural university classrooms?

\subsection{Literature Review}

A very recent study conducted at University of West Indies in Jamaica explored the views of students on using cell phones as a learning tool in the classroom. A survey was conducted with a sample of 25 students and the findings showed that cell phones were not causing any distraction to students. Moreover, they considered cell phones as an academic tool and it has enhanced their level of learning [13].

Ta'amneh [31] conducted a study at Taibah University in Saudi Arabia. The purpose of this study was to examine the views of students' use of smartphones in learning English language skills. A sample of 151 students participated in the study. A five-point Likert-type was the instrument used to collect the data. Findings showed that students did not have any difficulties in using smartphones for learning and they had positive attitudes on using smartphones as a learning tool.

Research conducted in a Malaysian university considered the time period the students have spent in using smartphones and explored how these devices have inclined their academic performance. A quantitative approach was employed for this study. A sample of 176 students from three faculties such as Administrative Management, Computer Science and Accounting were surveyed. The research found that even though majority of the students used smartphones for the learning activities, it did not reflect well in their academic performance [29].

Johnson and Radhakrishnan [32] investigated the use of smartphones in learning at a university in the United Arab Emirates. A questionnaire-based survey was conducted and the data were collected from 195 students of College of Business Studies. It was found that smartphones were used for academic purposes and it provided a positive impact in the classroom.

In an attempt to explore the educational perception of smartphones from 316 university students using a survey at Dhaka University in Bangladesh, Hossain and Ahmed [33] found that the participants had a positive attitude towards the use of smartphones for learning. Findings also showed that a huge majority of participants used smartphones for the purpose of recording lecture notes and accessing the academic materials.

Matto and Kazungu [34] studied the uses of chat apps and cell phones among 125 students at Lilongwe University of Agriculture and Natural Resources (LUANAR) in Malawi. A simple random sampling was used to select the respondents for this mixed method study. Questionnaires were distributed and interviews were conducted as a mean for data collection. This study found that chat apps in smartphones were not used by most of the survey respondents. This study also showed that students were using smartphones for the academic purpose such as searching for learning materials and storing it on phone, recording lectures, engaging with lecturers and classmates.

A study of 200 college students in Nilai was conducted by Salvation [35] to evaluate the importance of smartphone apps in the academic performance of students. This study employed quantitative approach and the design was survey. The results indicated that there exists a 
significant relationship between the students' use of educational apps in smartphones and their academic performance. Students enhanced their understanding and overall grade achievement since they used it as a tool for learning. However, the study also reported that it will diminish the students' classroom achievement if they spend more time in social apps.

A study was conducted in an undergraduate Food Science class. The aim of this study was to explore the perceptions of learning using Cell Phone-based Personal Response System (CPPRS) and their academic performance. A questionnaire was used to survey a sample of 28 students. Findings showed that the use of CPPRS in classroom has positively influenced students' learning [36].

\section{Materials and Methods}

\subsection{Research Methodology and Design}

A quantitative research methodology was employed for this study as it allowed articulating the facts and revealing the patterns in research. The study has chosen a descriptive research design as it gave a comprehensive description of the lecturers and PAL Tutors' views on students' use of smartphones for learning.

\subsection{Study Site, Population and Sample}

A total sample of 50 academics that was comprised of 39 lecturers from the Faculty of Business Science \& Management and Faculty of Science, Engineering \& Technology from a population of 71 and 11 PAL Tutors from Faculty of Science, Engineering \& Technology from a population of 14 voluntarily partook in the survey. The research was carried out at one of the campuses at a rural university located in Eastern Cape State of South Africa. It was convenient for the researchers to gather the data from the study site as both were working in the same campus of the same university. The researchers had the contact details of the participants in the aforementioned faculties which made the reason for selecting those two faculties for the study. PAL Tutors also teach as lecturers do which made the justification of collecting data from PAL Tutors.

\subsection{Data Collection Instrument}

The instrument used in the study was a structured questionnaire. The researchers developed the questionnaire and it consisted of two sections. The first section included the demographic questions such as types of participants (PAL Tutor and Lecturer), gender (Male and Female), age group (21-30, 31-40, 41-50 and Above 50) and faculty (Faculty of Business Science \& Management and Faculty of Science, Engineering \&
Technology). The second section included 10 statements (items) on 5-item Likert scale (level $1=$ "STRONGLY DISAGREE", level 2 = "DISAGREE", level 3 = "NO OPINION", level $4=$ "AGREE" and level $5=$ "STRONGLY AGREE") on the views of lecturers and PAL Tutors on students' use of smartphones for learning in rural university classrooms.

\subsection{Ethical Clearances}

Permission to conduct the study was obtained from relevant authorities and cleared all ethical issues. Furthermore, permission to collect the data was obtained from participants.

\subsection{Pilot Study}

The main researcher conducted a pilot study to measure the validity of the questionnaire on five lecturers who were not part of the main study and feedback received from the pilot study helped to make the questionnaire better. The reliability of the statements in the questionnaire was tested using Cronbach's alpha and the value was found to be 0.845 which is very appropriate for this study.

\subsection{Data Collection Procedure}

The researchers used Google form to enter the statements and develop the questionnaire. Thereafter, the uniform resource locator of the questionnaire was sent to the participants through WhatsApp and email. When the participants clicked on the uniform resource locator, they were directed to the first page of the survey that contained the informed consent form and purpose of the study. It was highlighted that the data collected would be confidential and requested for their voluntary participation. Each participant responded anonymously by signing the informed consent form. While the response rate of lecturers was 55\%, response rate of PAL Tutors was 79\%. The survey started on $28^{\text {th }}$ July 2020 at 12.00 AM and ended on $5^{\text {th }}$ August 2020 at 23.59 PM.

\subsection{Data Analysis}

The quantitative data were captured into Statistical Package for Social Sciences (version 26) which were analyzed using descriptive statistics and triangulated by sources among lecturers and PAL Tutors.

\section{Results}

It emerged that out of 50 students who participated in the study, $78 \%$ were lecturers and the remaining $22 \%$ were PAL Tutors. There were about 64\% male respondents and about 36\% female respondents. 


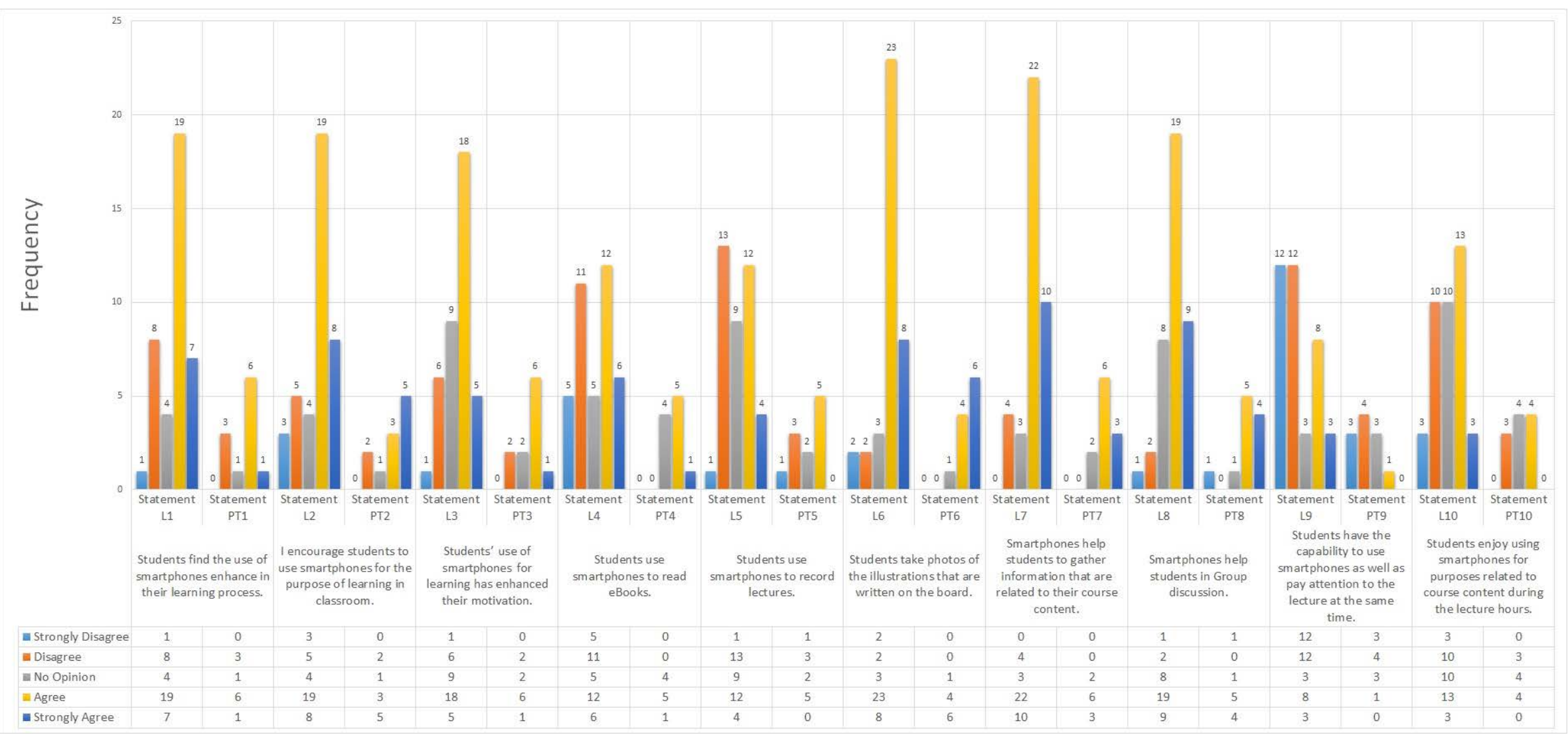

Figure 1. Triangulation of descriptive statistics of lecturers' and PAL Tutors views on students' use of smartphones for learning in rural university classrooms 
It emerged that more than one quarter (28\%) of the participants were in the age group of $21-30$. While $44 \%$ of the participants were in the age group of $31-40,18 \%$ of them were in the age group of $41-50$. A minor group of about $10 \%$ of the participants were in the age group of above 50.

Majority (80\%) of the participants in the study were from the Faculty of Science, Engineering \& Technology and the remaining $20 \%$ were from the Faculty of Business Science \& Management.

where $\mathrm{L}=$ Lecturers and PT=PAL Tutors

Table 1. Triangulation of descriptive statistics of lecturers' and PAL Tutors views on students' use of smartphones for learning in rural university classrooms

\begin{tabular}{|c|c|c|c|c|c|c|c|c|}
\hline STATEMENT & $\#$ & $\begin{array}{l}\text { Strongly } \\
\text { Disagree }\end{array}$ & Disagree & No Opinion & Agree & $\begin{array}{l}\text { Strongly } \\
\text { Agree }\end{array}$ & $\begin{array}{c}\text { Total } \\
\text { Attended }\end{array}$ & $\begin{array}{l}\text { Not } \\
\text { Answe } \\
\text { red }\end{array}$ \\
\hline \multirow{2}{*}{$\begin{array}{l}\text { Students find the use of } \\
\text { smartphones enhance in } \\
\text { their learning process. }\end{array}$} & L1 & $\begin{array}{c}1 \\
(2.6 \%)\end{array}$ & $\begin{array}{c}8 \\
(20.5 \%)\end{array}$ & $\begin{array}{c}4 \\
(10.3 \%)\end{array}$ & $\begin{array}{c}19 \\
(48.7 \%)\end{array}$ & $\begin{array}{c}7 \\
(17.9 \%)\end{array}$ & $\begin{array}{c}39 \\
(100 \%)\end{array}$ & 0 \\
\hline & PT1 & $\begin{array}{c}0 \\
(0 \%) \\
\end{array}$ & $\begin{array}{c}3 \\
(27.3 \%) \\
\end{array}$ & $\begin{array}{c}1 \\
(9.1 \%) \\
\end{array}$ & $\begin{array}{c}6 \\
(54.5 \%) \\
\end{array}$ & $\begin{array}{c}1 \\
(9.1 \%) \\
\end{array}$ & $\begin{array}{c}11 \\
(100 \%) \\
\end{array}$ & 0 \\
\hline \multirow{2}{*}{$\begin{array}{l}\text { I encourage students to } \\
\text { use smartphones for the } \\
\text { purpose of learning in } \\
\text { classroom. }\end{array}$} & L2 & $\begin{array}{c}3 \\
(7.7 \%) \\
\end{array}$ & $\begin{array}{c}5 \\
(12.8 \%) \\
\end{array}$ & $\begin{array}{c}4 \\
(10.3 \%) \\
\end{array}$ & $\begin{array}{c}19 \\
(48.7 \%) \\
\end{array}$ & $\begin{array}{c}8 \\
(20.5 \%) \\
\end{array}$ & $\begin{array}{c}39 \\
(100 \%) \\
\end{array}$ & 0 \\
\hline & PT2 & $\begin{array}{c}0 \\
(0 \%) \\
\end{array}$ & $\begin{array}{c}2 \\
(18.2 \%) \\
\end{array}$ & $\begin{array}{c}1 \\
(9.1 \%) \\
\end{array}$ & $\begin{array}{c}3 \\
(27.3 \%) \\
\end{array}$ & $\begin{array}{c}5 \\
(45.5 \%) \\
\end{array}$ & $\begin{array}{c}11 \\
(100 \%) \\
\end{array}$ & 0 \\
\hline \multirow{2}{*}{$\begin{array}{c}\text { Students' use of } \\
\text { smartphones for learning } \\
\text { has enhanced their } \\
\text { motivation. }\end{array}$} & L3 & $\begin{array}{c}1 \\
(2.6 \%)\end{array}$ & $\begin{array}{c}6 \\
(15.4 \%)\end{array}$ & $\begin{array}{c}9 \\
(23.1 \%)\end{array}$ & $\begin{array}{c}18 \\
(46.1 \%)\end{array}$ & $\begin{array}{c}5 \\
(12.8 \%)\end{array}$ & $\begin{array}{c}39 \\
(100 \%)\end{array}$ & 0 \\
\hline & PT3 & $\begin{array}{c}0 \\
(0 \%)\end{array}$ & $\begin{array}{c}2 \\
(18.2 \%) \\
\end{array}$ & $\begin{array}{c}2 \\
(18.2 \%)\end{array}$ & $\begin{array}{c}6 \\
(54.5 \%) \\
\end{array}$ & $\begin{array}{c}1 \\
(9.1 \%) \\
\end{array}$ & $\begin{array}{c}11 \\
(100 \%) \\
\end{array}$ & 0 \\
\hline \multirow{2}{*}{$\begin{array}{l}\text { Students use smartphones } \\
\text { to read eBooks. }\end{array}$} & L4 & $\begin{array}{c}5 \\
(12.8 \%) \\
\end{array}$ & $\begin{array}{c}11 \\
(28.2 \%) \\
\end{array}$ & $\begin{array}{c}5 \\
(12.8 \%) \\
\end{array}$ & $\begin{array}{c}12 \\
(30.8 \%) \\
\end{array}$ & $\begin{array}{c}6 \\
(15.4 \%) \\
\end{array}$ & $\begin{array}{c}39 \\
(100 \%) \\
\end{array}$ & 0 \\
\hline & PT4 & $\begin{array}{c}0 \\
(0 \%) \\
\end{array}$ & $\begin{array}{c}0 \\
(0 \%) \\
\end{array}$ & $\begin{array}{c}4 \\
(40 \%) \\
\end{array}$ & $\begin{array}{c}5 \\
(50 \%) \\
\end{array}$ & $\begin{array}{c}1 \\
(10 \%) \\
\end{array}$ & $\begin{array}{c}10 \\
(100 \%) \\
\end{array}$ & 1 \\
\hline \multirow{2}{*}{$\begin{array}{l}\text { Students use smartphones } \\
\text { to record lectures. }\end{array}$} & L5 & $\begin{array}{c}1 \\
(2.6 \%) \\
\end{array}$ & $\begin{array}{c}13 \\
(33.3 \%) \\
\end{array}$ & $\begin{array}{c}9 \\
(23.1 \%) \\
\end{array}$ & $\begin{array}{c}12 \\
(30.7 \%) \\
\end{array}$ & $\begin{array}{c}4 \\
(10.3 \%) \\
\end{array}$ & $\begin{array}{c}39 \\
(100 \%) \\
\end{array}$ & 0 \\
\hline & PT5 & $\begin{array}{c}1 \\
(9.1 \%) \\
\end{array}$ & $\begin{array}{c}3 \\
(27.3 \%) \\
\end{array}$ & $\begin{array}{c}2 \\
(18.2 \%) \\
\end{array}$ & $\begin{array}{c}5 \\
(45.4 \%) \\
\end{array}$ & $\begin{array}{c}0 \\
(0 \%) \\
\end{array}$ & $\begin{array}{c}11 \\
(100 \%) \\
\end{array}$ & 0 \\
\hline \multirow{2}{*}{$\begin{array}{l}\text { Students take photos of } \\
\text { the illustrations that are } \\
\text { written on the board. }\end{array}$} & L6 & $\begin{array}{c}2 \\
(5.3 \%) \\
\end{array}$ & $\begin{array}{c}2 \\
(5.3 \%)\end{array}$ & $\begin{array}{c}3 \\
(7.9 \%) \\
\end{array}$ & $\begin{array}{c}23 \\
(60.4 \%)\end{array}$ & $\begin{array}{c}8 \\
(21.1 \%)\end{array}$ & $\begin{array}{c}38 \\
(100 \%)\end{array}$ & 1 \\
\hline & PT6 & $\begin{array}{c}0 \\
(0 \%) \\
\end{array}$ & $\begin{array}{c}0 \\
(0 \%) \\
\end{array}$ & $\begin{array}{c}1 \\
(9.1 \%) \\
\end{array}$ & $\begin{array}{c}4 \\
(36.4 \%) \\
\end{array}$ & $\begin{array}{c}6 \\
(54.5 \%) \\
\end{array}$ & $\begin{array}{c}11 \\
(100 \%) \\
\end{array}$ & 0 \\
\hline \multirow{2}{*}{$\begin{array}{c}\text { Smartphones help } \\
\text { students to gather } \\
\text { information that are } \\
\text { related to their course } \\
\text { content. } \\
\end{array}$} & L7 & $\begin{array}{c}0 \\
(0 \%)\end{array}$ & $\begin{array}{c}4 \\
(10.3 \%)\end{array}$ & $\begin{array}{c}3 \\
(7.7 \%)\end{array}$ & $\begin{array}{c}22 \\
(56.4 \%)\end{array}$ & $\begin{array}{c}10 \\
(25.6 \%)\end{array}$ & $\begin{array}{c}39 \\
(100 \%)\end{array}$ & 0 \\
\hline & PT7 & $\begin{array}{c}0 \\
(0 \%) \\
\end{array}$ & $\begin{array}{c}0 \\
(0 \%) \\
\end{array}$ & $\begin{array}{c}2 \\
(18.2 \%) \\
\end{array}$ & $\begin{array}{c}6 \\
(54.5 \%) \\
\end{array}$ & $\begin{array}{c}3 \\
(27.3 \%) \\
\end{array}$ & $\begin{array}{c}11 \\
(100 \%) \\
\end{array}$ & 0 \\
\hline \multirow{2}{*}{$\begin{array}{l}\text { Smartphones help } \\
\text { students in Group } \\
\text { discussion. }\end{array}$} & L8 & $\begin{array}{c}1 \\
(2.6 \%) \\
\end{array}$ & $\begin{array}{c}2 \\
(5.1 \%) \\
\end{array}$ & $\begin{array}{c}8 \\
(20.5 \%) \\
\end{array}$ & $\begin{array}{c}19 \\
(48.7 \%) \\
\end{array}$ & $\begin{array}{c}9 \\
(23.1 \%) \\
\end{array}$ & $\begin{array}{c}39 \\
(100 \%) \\
\end{array}$ & 0 \\
\hline & PT8 & $\begin{array}{c}1 \\
(9.1 \%) \\
\end{array}$ & $\begin{array}{c}0 \\
(0 \%) \\
\end{array}$ & $\begin{array}{c}1 \\
(9.1 \%) \\
\end{array}$ & $\begin{array}{c}5 \\
(45.4 \%) \\
\end{array}$ & $\begin{array}{c}4 \\
(36.4 \%) \\
\end{array}$ & $\begin{array}{c}11 \\
(100 \%) \\
\end{array}$ & 0 \\
\hline \multirow{2}{*}{$\begin{array}{l}\text { Students have the } \\
\text { capability to use } \\
\text { smartphones as well as } \\
\text { pay attention to the } \\
\text { lecture at the same time. }\end{array}$} & L9 & $\begin{array}{c}12 \\
(31.6 \%) \\
\end{array}$ & $\begin{array}{c}12 \\
(31.6 \%) \\
\end{array}$ & $\begin{array}{c}3 \\
(7.9 \%) \\
\end{array}$ & $\begin{array}{c}8 \\
(21.0 \%) \\
\end{array}$ & $\begin{array}{c}3 \\
(7.9 \%) \\
\end{array}$ & $\begin{array}{c}38 \\
(100 \%) \\
\end{array}$ & 1 \\
\hline & PT9 & $\begin{array}{c}3 \\
(27.3 \%)\end{array}$ & $\begin{array}{c}4 \\
(36.3 \%)\end{array}$ & $\begin{array}{c}3 \\
(27.3 \%)\end{array}$ & $\begin{array}{c}1 \\
(9.1 \%)\end{array}$ & $\begin{array}{c}0 \\
(0 \%)\end{array}$ & $\begin{array}{c}11 \\
(100 \%)\end{array}$ & 0 \\
\hline \multirow{2}{*}{$\begin{array}{l}\text { Students enjoy using } \\
\text { smartphones for purposes } \\
\text { related to course content } \\
\text { during the lecture hours. }\end{array}$} & L10 & $\begin{array}{c}3 \\
(7.7 \%) \\
\end{array}$ & $\begin{array}{c}10 \\
(25.6 \%) \\
\end{array}$ & $\begin{array}{c}10 \\
(25.6 \%)\end{array}$ & $\begin{array}{c}13 \\
(33.4 \%) \\
\end{array}$ & $\begin{array}{c}3 \\
(7.7 \%) \\
\end{array}$ & $\begin{array}{c}39 \\
(100 \%) \\
\end{array}$ & 0 \\
\hline & $\begin{array}{c}\text { PT1 } \\
0 \\
\end{array}$ & $\begin{array}{c}0 \\
(0 \%) \\
\end{array}$ & $\begin{array}{c}3 \\
(27.2 \%) \\
\end{array}$ & $\begin{array}{c}4 \\
(36.4 \%) \\
\end{array}$ & $\begin{array}{c}4 \\
(36.4 \%) \\
\end{array}$ & $\begin{array}{c}0 \\
(0 \%) \\
\end{array}$ & $\begin{array}{c}11 \\
(100 \%) \\
\end{array}$ & 0 \\
\hline
\end{tabular}


After the data were triangulated by sources among lecturers and PAL Tutors, it was observed that $48.7 \%$ of the lecturers agreed and $17.9 \%$ of them strongly agreed that the use of smartphones enhanced students in their learning process. (statement L1). While $2.6 \%$ of the lecturers strongly disagreed and $20.5 \%$ of them disagreed, $10.3 \%$ of them were uncertain. More than half (54.5\%) of the PAL Tutors agreed and $9.1 \%$ of them strongly agreed on statement PT1. While $27.3 \%$ of the PAL Tutors disagreed, $9.1 \%$ of them were uncertain.

It can be seen that $48.7 \%$ of the lecturers agreed and $20.5 \%$ of them strongly agreed that lecturers did encourage students to use smartphones for the purpose of learning in classroom (statement L2). While $7.7 \%$ of the lecturers strongly disagreed, $12.8 \%$ of them disagreed on statement L2. Around $10.3 \%$ of them did not have any opinion. Around $27.3 \%$ of the PAL Tutors agreed and almost half (45.5\%) of them strongly agreed on statement PT2. About $18.2 \%$ of them disagreed and $9.1 \%$ of them were indeterminate.

It was observed that $46.1 \%$ of the lecturers agreed and $12.8 \%$ of them strongly agreed that use of smartphones for learning enhanced students' motivation (statement L3). About $2.6 \%$ of the lecturers strongly disagreed and $15.4 \%$ of them disagreed. Around $23.1 \%$ of them were indeterminate. While $54.5 \%$ of the PAL Tutors agreed and $9.1 \%$ of them strongly agreed on statement PT3, $18.2 \%$ of them disagreed. Another $18.2 \%$ of them were uncertain.

Statement L4 revealed that almost $30.8 \%$ of the lecturers agreed and $15.4 \%$ of them strongly agreed that students did use smartphones to read eBooks (statement L4). About $12.8 \%$ of the lecturers strongly disagreed and $28.2 \%$ of them disagreed on statement L4. Around $12.8 \%$ of them were indeterminate. While half of the PAL Tutors (50\%) agreed and $10 \%$ of them strongly agreed on statement PT4, $40 \%$ of them did not have any opinion. One of them did not attend.

It emerged that $30.7 \%$ of the lecturers agreed and $10.3 \%$ of them strongly agreed that students did use smartphones to record lectures (statement L5). While 2.6\% of the lecturers strongly disagreed and $33.3 \%$ of them disagreed on statement L5, 23.1\% of them were uncertain. Around $45.4 \%$ of the PAL Tutors agreed on statement PT5. While $9.1 \%$ of them strongly disagreed and $27.3 \%$ of them disagreed, $18.2 \%$ of them were indeterminate.

It can be seen that $60.4 \%$ of the lecturers agreed and $21.1 \%$ of them strongly agreed that students did take photos of the illustrations that are written on the board (statement L6). About $7.9 \%$ of them did not have any opinion. Around $5.3 \%$ of the lecturers strongly disagreed and another 5.3\% of them disagreed on statement L6. One of them did not attend. More than one third (36.4\%) of the PAL Tutors agreed and more than half (54.5\%) of them strongly agreed on PT6. About 9.1\% of them did not have any opinion.

It was clear that more than half (56.4\%) of the lecturers agreed and $25.6 \%$ of them strongly agreed that smartphones did help students to gather information that are related to their course content (statement L7). While about $10.3 \%$ of the lecturers disagreed on statement L7, around $7.7 \%$ of them preferred a neutral stance. More than half (54.5\%) of the PAL Tutors agreed and more than one quarter (27.3\%) of them strongly agreed on statement PT7. About $18.2 \%$ of them were uncertain.

Statement L8 revealed that $48.7 \%$ of the lecturers agreed and $23.1 \%$ of them strongly agreed that smartphones did help students in Group discussion (statement L8). About $2.6 \%$ of the lecturers strongly disagreed and $5.1 \%$ of them disagreed on statement L8. Around $20.5 \%$ of them were indeterminate. Almost half (45.4\%) of the PAL Tutors agreed and more than one third (36.4\%) of them strongly agreed on statement PT8. While $9.1 \%$ of them strongly disagreed on statement PT8, another $9.1 \%$ of them preferred a neutral stance.

About $21 \%$ of the lecturers agreed and $7.9 \%$ of them strongly agreed that students did have the capability to use smartphones as well as pay attention to the lecture at the same time (statement L9). While $31.6 \%$ of the lecturers strongly disagreed on statement L9, another $31.6 \%$ of them disagreed and $7.9 \%$ of them were indeterminate. Around $9.1 \%$ of the PAL Tutors agreed on statement PT9. More than one quarter (27.3\%) of the PAL Tutors strongly disagreed and more than one third (36.3\%) of them disagreed on statement PT9. However, 27.3\% of them were uncertain.

It emerged that $33.4 \%$ of the lecturers agreed and $7.7 \%$ of them strongly agreed that students did enjoy using smartphones for purposes related to course content during the lecture hours (statement L10). While $7.7 \%$ of the lecturers strongly disagreed and $25.6 \%$ of them disagreed on statement L10, another $25.6 \%$ of them did not have any opinion. While more than one third (36.4\%) of the PAL Tutors agreed and another $36.4 \%$ of them preferred a neutral stance on statement PT10, 27.2\% of them disagreed.

\section{Discussion}

Findings obtained after triangulation by sources among lecturers and PAL Tutors revealed that students used smartphones to enhance their learning process. A study conducted by Ma et al. [36] showed that smartphone is a useful and user-friendly tool for improving students' learning and academic performance. Therefore, findings of the current study concur with the views of Ma et al. [36]. This attitude of students shows that they are very much keen in studying using smartphones.

From the findings, it is evident that many of the lecturers encouraged their students to use smartphone for the purpose of learning in classroom. A study conducted by Kadry and Roufayel [37] proposed a mobile learning 
application that makes the particular course more active and dynamic which encourages students to use their smartphones for an effective learning. Tessier [38] suggested mobile phones enhanced students' learning process, encouraged them to use the mobile phones and attend the class. Findings of the present study are therefore consistent with the findings by Kadry and Roufayel [37]and Tessier [38]. According to the view of the researchers of the current study, lecturers want their students to be updated with the latest technologies to integrate those in their learning.

It can be seen that students' use of smartphones enhanced their motivation for learning process. Students' level of motivation had enhanced by harnessing the potential of smartphone technologies [39]. Pegrum, Oakley, \& Faulkner [40] averred that mobile devices enhanced motivation and engagement of students with empirical evidence of improved student learning. Findings of the present study are in agreement with Seifert [39] and Pegrum et al. [40]. Since mobile learning can be done at any time anywhere, students are highly motivated to learn their course content using their smartphones.

It emerged from the study that students used smartphones to read eBooks. Lo et al. [41] averred that students' use of smartphones for reading e-books and journal articles was minimal. Therefore, findings of the present study contradict the results of the study by Lo et al. [41]. Reading eBooks using smartphones is very convenient for students especially if the smartphones are with big screen as they do not need to carry heavy textbooks.

The study established that students used smartphones to record lectures in the classroom. Mtega et al. [42] indicated that only a minority of the students used their mobile phones for recording lectures. Therefore, findings of the current study refute the findings by Mtega et al. [42]. This approach of students recording the lecture enables them to play the video as and when in need.

The study further established that students took photos of the illustrations that are written on the board. This is similar to the results found by Shrivastava and Shrivastava [43] who stated that students used their mobile phones to take photos of the diagrams drawn on the board. Taking snapshots of the illustrations help to avoid mistakes if they draw on their notebooks.

Most of the students used smartphones to gather information that are related to their course content which is in line with investigations by Matto and Kazungu [34] who affirmed that one of the most academic uses of mobile phones was searching for academic materials on the internet. Gathering information using smartphone enhances students' learning skill.

The results of this study showed that smartphones helped students in Group discussion. Blasco [44] found that students enjoyed the group discussions when they were allowed to use their mobile phones. Findings of this study coincide with the results obtained by Blasco [44]. Smartphones help the students to prepare easily for the group discussion.

The research found that students did not have the capability to use smartphones as well as pay attention to the lecture at the same time. Pulliam [45] also posited that students can focus on only one activity at a time and they do not have the capability to do multitasking. Therefore, finding of the current study is in parallel with the finding by Pulliam [45]. The researchers of this study view that doing multitasking such as listening to lecture and using smartphones simultaneously distracts lecturers and other students as it affects the smooth running of the class.

Furthermore, this research showed that students enjoyed using smartphones for purposes related to course content during the lecture hours which is in line with investigations by Ahmad [13] who stated that students enjoyed using their mobile phones as a learning tool during class discussions. Students' enjoyment using smartphones in learning shows that they are becoming more enthusiastic about the course.

\section{Conclusions}

On the basis of the data presented and analyzed in this study, it showed that lecturers and PAL Tutors had positive attitudes towards the students' use of smartphones in rural university classrooms. Smartphones helped students in group discussion and to gather information that are related to their course content. It has been strongly established that students do not have the multitasking capability of using smartphones and paying attention to lecture at the same time. However, they took photos of the illustrations that are written on the board. Generally, the findings of this study showed that use of smartphones for academic purposes in university classrooms were enjoyed by the students and it was enhancing their motivation and learning process.

There are some potential limitations to this study. The total number of lecturers and PAL Tutors participated in this study was not at large. Secondly, this study was limited to lecturers from Faculty of Business Science \& Management and Faculty of Science, Engineering \& Technology and PAL Tutors from Faculty of Science, Engineering \& Technology. It would have been better if more lecturers and PAL Tutors from other faculties were also included in this study to increase the sample size.

The study recommends that universities which restrict the use of smartphones in the classroom should reconsider their policy to integrate smartphone in learning and teaching as it influences, motivates and helps students to study their daily portions smartly.

From the findings of this study, it would be more constructive to conduct further research by doing a comparative study on the perception of lecturers and PAL 
Tutors on the students' use of smartphones in other countries with the perception of lecturers and PAL Tutors in South Africa. Research on students' personal use of smartphones during class time would also be a constructive study to be investigated.

\section{REFERENCES}

[1] Tanjga, M., “Ad-hoc e-learning measures during COVID-19 lockdown in Republic of Srpska HE institutions: student insights," Research square, 2021. DOI: 10.21203/rs.3.rs-352095/v1

[2] Hall, M., Elliot, K. M., "Diffusion of technology into the teaching process: Strategies to encourage faculty members to embrace the laptop environment," Journal of Education for Business, vol. 78, no. 6, pp. 301-307, 2003. DOI: $10.1080 / 08832320309598617$

[3] Brown, D. G., Petitto, K. R., "The status of ubiquitous computing,” Educase Review, vol. 38, pp. 25-33, 2003.

[4] Brown, D.G., Burg, J.J., Dominick, J.L., "A Strategic Plan for Ubiquitous Laptop Computing," Communications of the ACM, vol. 41, pp. 26-35, 1998.

[5] Ali, B., "Evaluation of challenges faced by the teachers and students of two further education institutions when using the iPad in the teaching and learning of English as a foreign language Fujairah, United Arab Emirates,” Eastern Journal of Languages, Linguistics and Literatures”, vol. 1, no. 2, pp. 1-10, 2021. DOI: 10.6084/ejlll.v1i2.15

[6] Li, Y., Wang, L., "Using Ipad-based mobile learning to teach creative engineering within a problem-based learning pedagogy," Education and Information Technologies, vol. 23, no. 1, pp. 555-568, 2018.

[7] Agir, A., "iPad at School: A Holistic Evaluation of the Opinions of Students, Teachers and Parents concerning iPad Use,” International Journal of Education, vol. 7, no. 3, pp. 175-193, 2015.

[8] Mango, O., "iPad Use and Student Engagement in the Classroom," Turkish Online Journal of Educational Technology, vol. 14, no. 1, pp. 53-57, 2015

[9] Shehu, S. A., Muhammed, B., "Integration of Mobile Technology in Instructional Process and Perception of its uses in Tertiary Institutions,” Kano Journal of Educational Psychology, vol. 2, no. 1, pp. 143-151, 2020.

[10] Şendağ, S., Gedik, N., Toker, S., "Impact of repetitive listening, listening-aid and podcast length on EFL podcast listening," Computers \& Education, vol. 125, pp. 273-283, 2018.

[11] McKinney, D., Dyck, J. L., Luber, E. S., “iTunes university and the classroom: Can podcasts replace professors?," Computers \& Education, vol. 52, no. 3, pp. 617-623, 2009.

[12] Zogheib, B., Daniela, L., "Students' Perception of Cell Phones Efect on their Academic Performance: A Latvian and a Middle Eastern University Cases,” Technology, Knowledge and 2021.

\section{DOI:10.1007/s10758-021-09515-4.}

[13] Ahmad T., "Mobile phones as a learning tool: a lecturer's viewpoint," Society and Business Review, vol. 13, no. 2, pp. 132-139. 2018. DOI: 0.1108/SBR-03-2018-0021.

[14] [14] Menkhoff, T., Bengtsson, M., “Engaging Students in Higher Education Through Mobile Learning: Lessons Learnt in a Chinese Entrepreneurship Course,” Educational Research for Policy and Practice, vol. 11, pp. 225-242, 2012.

[15] Wang, N., Chen, J., Tai, M., Zhang, J., "Blended learning for Chinese university EFL learners: learning environment and learner perceptions,“ Computer Assisted Language Learning, vol. 34, no. 3, pp. 297-323, 2021. DOI: 10.1080/09588221.2019.1607881.

[16] Tagoe, M., Abakah, E., "Determining distance education students' readiness for mobile learning at University of Ghana using the Theory of Planned Behavior,” International Journal of Education and Development using Information and Communication Technology, vol. 10, no. 1, pp. 91-106, 2014.

[17] Darko-Adjei, N., "The use and effect of smartphones in students' learning activities: evidence from the university of Ghana, legon,” Library Philosophy and Practice, pp. 2851, 2019.

[18] Kumar, M., "Impact of the Evolution of Smart Phones in Education Technology and its Application in Technical and Professional Studies: Indian Perspective,” International Journal of Managing Information Technology, vol. 3, no. 3, pp. 39-49, 2011. DOI : 10.5121/ijmit.2011.3304 39.

[19] Norries, C., Hossain, A., Soloway, E., “Using smartphones as essential tools for learning: A call to place schools on the right side of the 21st century,” Educational Technology, vol. 51, no. 3, pp. 18-25, 2011.

[20] Dukic, Z., Chiu, D. K. W. \& Lo, P., "How useful are smartphones for learning? Perceptions and practices of Library and Information Science students from Hong Kong and Japan,” Library Hi Tech, vol. 33, no. 4, pp. 545-561, 2015. DOI: 10.1108/LHT-02-2015-0015.

[21] Masadeh, T. S. Y., "Smartphone use in learning as perceived by university undergraduates: benefits and barriers,” International Journal of Research, vol. 9, no. 3, pp. 56 - 65, 2021. DOI: 10.29121/granthaalayah.v9.i3.2021.37 64.

[22] Twum, R., "Utilization of Smartphones in Science Teaching and Learning in Selected Universities in Ghana," Journal of Education and Practice, vol. 8, no. 7, pp. 216-228, 2017.

[23] Global System for Mobile Communications Intelligence, 2017, https://www.gsmaintelligence.com/ research/?file=7 bf3592e6d750144e58d9dcfac6adfab\&download (accessed February. 27, 2021).

[24] Kaliisa, R., \& Picard, M., “A Systematic Review on Mobile Learning in Higher Education: The African Perspective," Turkish Online Journal of Educational Technology-TOJET, vol. 16, no. 1, pp. 1-18, 2017. DOI: 10.1017/CBO9781107 415324.004

[25] North, D. , Johnston, K., \& Ophoff, J., "The use of mobile 
phones by South African university students,” Issues in Informing Science and Information Technology, vol. 11, pp. 115-138, 2014.

[26] Ossiannilsson, E., "Quality enhancement for mobile learning in higher education," in Human Computer Interaction: Concepts, Methodologies, Tools, and Applications, IGI Global, 2015, pp. 2092-2107.

[27] Chittaranjan, G., Blom, J., Gatica-Perez, D., "Mining large-scale smartphone data for personality studies," Personal and Ubiquitous Computing, vol. 17, pp. 433-450, 2011.

[28] Tossell, C. C., Kortum, P., Shepard, C., Barg-Walkow, L. H., Rahmati, A., "A longitudinal study of emoticon use in text messaging from smart phones,” Computers in Human Behavior, vol. 28, pp. 659-663, 2012.

[29] Ng, S. F., Hassan, N. S. I. C., Nor, N. H. M., \& Malek, N. A. A. (2017). The Relationship Between Smartphone Use and Academic Performance: A Case of Students in a Malaysian Tertiary Institution. Malaysian Online Journal of Educational Technology, 5 (4), 58-70.

[30] Masiu, T. M. \& Chukwuere, J., "The Effect of Smartphones on Students' Academic Life: A Perceptive from A South African University," Conference: International Conference on Business and Management Dynamics ICBMD-2018, Cape Town, South Africa , November., 2018, pp.174-183. DOI: https://www.researchgate.net/profile/Joshua-Chukwu ere/publication/329093587_The_Effect_of_Smartphones_ on_Students'_Academic_Life_A_Perceptive_from_A_Sou th_African_University/links/5bf554f892851c6b27cf00c2/ The-Effect-of-Smartphones-on-Students-Academic-Life-A -Perceptive-from-A-South-African-University.pdf

[31] Ta'amneh, M. A. A. A., "The Use of Smartphones in Learning English Language Skills: A Study of University Students' Perspectives,” International Journal of Applied Linguistics \& English Literature, vol. 10, no. 1, pp. 1-8, 2021. DOI: 10.7575/aiac.ijalel.v.10n.1p.1.

[32] Johnson, S., Radhakrishnan, N. "Academic use of smart phones among the students of business schools in uae - a study," KIIT Journal of Library and Information Management, vol. 4, no. 1, pp. 32-36, 2017.

[33] Hossain, M. E., Ahmed, S. M. Z., "Academic use of smartphones by university students: A developing country perspective,” The Electronic Library, vol. 34, no. 4, pp. 651-665, 2016.

[34] Matto, G., Kazungu, I., "Mobile phone and chat apps usage among Malawian university Students: luanar's experience," Research Report Series (RRS), vol. 2, no. 1, pp. 73-85, 2018.
[35] Salvation, M. D., "The relationship between smartphone applications usage and students' academic performance," Computational Methods in Social Sciences, pp. 26-39, 2017.

[36] Ma, S., Steger, D. G., Doolittle, P. E., Stewart, A. C., "Improved Academic Performance and Student Perceptions of Learning through Use of a Cell Phone-Based Personal Response System,” Journal of Food Science Education, vol. 17, pp. 27-32. 2018.

[37] Kadry, S. \& Roufayel, R., "How to Use Effectively Smartphone in the Classroom," Conference: IEEE Educon Conference 2017, Athens, Greece, April., 2017, pp. 441-447. DOI:10.1109/EDUCON.2017.7942884.

[38] Tessier, J., "Student impressions of academic cell phone use in the classroom,” Journal of College Science Teaching, vol. 43, no. 1, pp. 25-29, 2013.

[39] Seifert, T., "Pedagogical applications of smartphone integration in teaching: Lecturers, pre-service teachers and pupils perspectives,” International Journal of Mobile and Blended Learning, vol. 7, no. 2, pp. 1-16, 2015.

[40] Pegrum, M., Oakley, G., Faulkner, R., "Schools going mobile: A study of the adoption of mobile handheld technologies in Western Australian independent schools," Australasian Journal of Educational Technology, vol. 29, no. 1, pp. 66-81, 2013.

[41] Lo, P., Cho, A., Leung, M., Chiu, D.K.W., Ko, E.H.T., Ho, K.K.W., "Use of smartphones by art and design students for accessing library services and learning,” Library Hi Tech, vol. 34, no. 2, pp. 224-238, 2016.

[42] Mtega, W. P., Bernard, R. P., Msungu, A. C., \& Sanare, R., "Using Mobile Phones for Teaching and Learning Purposes in Higher Learning Institutions: The Case of Sokoine University of Agriculture in Tanzania," Proceedings and report of the 5th UbuntuNet Alliance annual conference, 2012.

[43] Shrivastava, A., Shrivastava, M., "Classroom Distraction Due to Mobile Phones Usage by Students: College Teachers' Perceptions," International Journal of Computer and Information Technology, vol. 3, no. 3, pp. 638 - 642, 2014.

[44] Blasco, D., "Student's attitudes toward integrating mobile technology into translation activities,” International Journal on Integrating Technology in Education, vol. 5, no. 1, pp. 1-11. 2016.

[45] Pulliam D., "Effect of Student Classroom Cell Phone Usage on Teachers," Masters Theses \& Specialist Projects. Western Kentucky University, 2017. 